\title{
Desalination Technique on Seaweeds Hydrolysate Eucheuma Cottonii for Bioethanol Production
}

\author{
Jaini Fakhrudin ${ }^{1 *}$, Dwi Setyaningsih², Mulyorini Rahayuningsih ${ }^{2}$ \\ ${ }^{1}$ Pontianak State Polytechnic, Pontianak, Indonesia \\ ${ }^{2}$ IPB University, Bogor, Indonesia \\ *Corresponding authorE-mail: jai_fakh@yahoo.com
}

\begin{abstract}
Manuscript received 15 August 2021; revised 1 Sept 2021; accepted 15 Sept 2021. Date of publication 4 Nov 2021
Abstract

The dissolved salts on Eucheuma cottonii hydrolysate interfere the growth of $S$. cerevisiae in the fermentation as it is considered as inhibitors. These salts are derived from biomass and formed from the chemicals used for hydrolysis processes such as $\mathrm{H}_{2} \mathrm{SO}_{4}$ and $\mathrm{CaOH}_{2}$. Ions and cations of the salts are potential as inhibitors such as $\mathrm{Na}^{+}, \mathrm{Cl}-, \mathrm{NH}_{4}{ }^{+}, \mathrm{SO}_{4}{ }^{2-}$. Osmotic pressure is raised due to the presence of salt. The efforts had been made to reduce salinity level through electrodialysis. The objective of this study was to eliminate dissolved salts in the hydrolysate in order to optimize the process of fermentation and increase ethanol yield. The results showed that the process of desalination by electrodialysis was able to reduce the salinity of $20 \%$ on the voltage of $5 \mathrm{~V}$ for 30 minutes; the voltage $9 \mathrm{~V}$ for 15 minutes; the voltage $12 \mathrm{~V}$ for 30 minutes. The lowest decline of $\mathrm{SO}_{4}^{2-}$ occurred at treatment of $12 \mathrm{~V}$ for 45 minutes. The content of sulfate in the treatment decreased to $2.97 \mathrm{~g} / \mathrm{l}$ or $46.22 \%$. The more sulfate is reduced through the electrodialysis process, the better the fermentation process is carried out. Desalination treatment at a voltage of $5 \mathrm{~V}$ for 30 minutes had been the best treatment because it produced the highest ethanol yield of $2.06 \%$. All the voltage treatments and the length of time on the electrodialysis process had a significant influence on the levels of ethanol yield. The process of desalination by electrodialysis was able to reduce the levels of dissolved salts, then it had a significant effect on ethanol yield.
\end{abstract}

Keywords: Bioethanol, Eucheuma Cottonii, Desalination, Electrodialysis.

\section{Introduction}

World oil reserves have been declining because of the increasing of the consumption in line with the increasing number of people, while the natural resources cannot be renewed. Ramachandra \& Hebbale indicated that challenges have been raised by fossil fuels for the transport and manufacturing industries, such as the depletion of fossil fuel supplies, increased greenhouse gas (GHG), and imminent climate change [1]. This situation is triggering many countries to look for alternative sources as renewable and sustainable energy.

Indonesia as the world's fourth-largest population should have good energy security. The efforts that can be done are to empower the potency of the abundant natural resources as raw materials of bioenergy production and to reduce the dependence on fossil-based energy as occurred over the years.

For many decades, the need for bioethanol has been rising. This is needed since bioethanol is used as an additive to gasoline [2]. Bioethanol can be used as an alternative fuel by mixing it with gasoline, known as gasohol, for instance, E5 (5\% ethanol), E10 (10\% ethanol). It can be used without the need for any engine or fuel system modification in the internal combustion engines of most modern cars and light-duty vehicles. The use of gasohol will also increase the octane number and produce relatively lower emissions than regular gasoline.

Seaweed Eucheuma cottonii can be used as an alternative raw material for the production of bioethanol. Eucheuma spp. contains great amounts of polysaccharides and has a high content of carbohydrates [3] [4]. As a cell wall part, the polysaccharides are mostly in the form of carrageenan. Carrageenan is a linear, sulfated polysaccharide with alternating alpha (1-3)-D-galactose-4-sulphate and $\beta$ (1,4)-3, 6-anhydrous-D-galactose residues forming the primary structure [5] [6]. The content of galactose in E. cottonii is then converted into ethanol. The fixed bioethanol price obtained from E. cottonii is compatible with that obtained from other feedstocks [7] [8].

Hydrolysate with a high sugar content does not always contain a higher yield of ethanol than hydrolysate with a low sugar because certain inhibitions of microorganism growth in fermentation can occur. Inhibitory compounds are released during the pretreatment processes [3], [5], [7]. Sunwoo et al. indicated that reducing sugar compounds with extended treatment periods have been converted to inhibitory compounds [9] [6]. Factors that may be inhibiting the growth of S. cerevisiae are salts on the substrate. Salts can be formed from the raw materials and the chemicals used [10]. Anions such as $\mathrm{Cl}^{-}$and $\mathrm{SO}_{4}{ }^{2-}$ show a significant effect on the inhibition of the growth of the microorganisms in the fermentation. High salt concentrations cause osmotic stress and ion toxicity [11]. 
The weakness of the use of $\mathrm{Ca}(\mathrm{OH})_{2}$ as the alkali detoxification is the formation of $\mathrm{CaSO}_{4}$. The presence of CaSO 4 could be inhibiting the growth of microbes. The fermentation process can be inhibited by high salt concentrations, so decreasing the salt concentration is necessary. Efforts are being made to reduce the salt content is by electrodialysis techniques. This technique is able to reduce the salt content up to $91.5 \%$ and relatively did not affect the levels of reducing sugars in the hydrolysate [12].

The study aimed to evaluate the effectiveness of electrodialysis in the removal of dissolved salts in hydrolysates $E$. cottonii so that the fermentation process runs well and the production of bioethanol increased. This research shows that dissolved salt and salinity levels decrease significantly through the desalination process by electrodialysis. As a result, the process can increase the ethanol yield.

\section{Literature Review}

\subsection{Desalination Through Electrodialysis}

The efficiency of the use of sugar in the fermentation process is still low due to the presence of dissolved salts resulting from acid hydrolysis and neutralization of $\mathrm{Ca}(\mathrm{OH})_{2}$ in the hydrolysate which interferes with the fermentation process. Desalination is a separation process carried out to reduce the dissolved salt content of a substrate. Salt is an ionic compound formed by the reaction between an acid and a base such as the following reaction:

$$
\mathrm{H}_{2} \mathrm{SO}_{4}(\mathrm{aq})+\mathrm{Ca}(\mathrm{OH})_{2}(\mathrm{aq})-->\mathrm{CaSO}_{4}(\mathrm{aq})+2 \mathrm{H}_{2} \mathrm{O}(\mathrm{l})
$$

The ionic equation is as follows:

$$
2 \mathrm{H}+\mathrm{SO}_{4}{ }^{2-}+\mathrm{Ca}_{2}+2 \mathrm{OH}-\rightarrow \mathrm{Ca}_{2}+\mathrm{SO}_{4}{ }^{2-}+2 \mathrm{H}+2 \mathrm{OH}-
$$

Electrodialysis is a separation process using a cation exchange membrane. The transfer of ions occurs due to the difference in electric voltage. Positive ions in the chamber will diffuse through the membrane to the cathode, and negative ions will diffuse to the anode. Through this process, the salts contained in the hydrolysate will exit through the membrane because of the charge on the salt.

\subsection{Eucheuma Cottonii}

Seaweed growth is characterized by increasing total weight. Based on the weights of the seaweed after 40 days, all of the seaweed in the observations had grown. E. cottonii had its highest daily growth rate (DGR) on day 20, then began to fall by the end of day 40 . The daily growth rate of E. cottonii seaweed is correlated with salinity, brightness, phosphate, and nitrate [13].

Eucheuma cottonii is a red algae that could also synthesize carrageenan and other polysaccharides. Carrageenan is a hydrocolloid composed of potassium, sodium, magnesium, and potassium sulfate esters with galactose 3.6 anhydrogalactose co-polymer. Carrageenan is a sulfated polysaccharide with a high molecular weight that is found in the cell walls of red seaweed and interacts with other bioactive molecules such as proteins, lipids, pigments, and other polysaccharides [14].

\subsection{Bioethanol}

Bioethanol is the most widely used biofuel in the world, and it can be used to replace gasoline or to create other gasoline-ethanol blends. It is also a crucial component in the production of a variety of high-value chemicals (e.g., acetaldehyde, ethylene, 1,3-butadiene, ethyl acetate).

To meet sustainability goals, bioethanol is now produced from lignocellulosic feedstocks, non-food crops, or industrial waste and residue streams [15]. Bioethanol is produced by fermentation using biological raw materials, while ethanol can be produced by synthesis through the catalytic hydration of ethylene. The physical properties of ethanol are polar due to its hydroxyl group (R-OH). Like water, ethanol can form hydrogen bonds. Because of this hydrogen bond, ethanol has a higher boiling point than other compounds with the same formula weight. Ethanol is also volatile, flammable and boils at $78^{\circ} \mathrm{C}$.

\section{Methods}

\subsection{Yeast and Media}

Potato Dextrose Agar (PDA) for yeast regeneration was purchased commercially. The yeast used was Saccharomyces cerevisiae and was cultivated on PDA, previously sterilized for 15 minutes at a temperature of $121^{\circ} \mathrm{C}$ and a pressure of $1 \mathrm{~atm}$, then incubated for 3 days at $30^{\circ} \mathrm{C}$. Microbes on PDA as a culture stock were regenerated for 24 hours at $30^{\circ} \mathrm{C}$ on the yeast extract Maltose Glucose Peptone (YMGP) media.

\subsection{Hydrolysis Process}

Seaweed used was E. cottonii. It was soaked for two days to remove a wide range of dissolved salts. It is an initial step in the desalination process for the elimination of seaweed salts. Seaweed was characterized by include analysis of the carbohydrate content (SNI 01-28911992) and water content. Acid hydrolysis was performed to breakdown a polysaccharide in the seaweed. This used $3 \%$ sulfuric acid $\left(\mathrm{H}_{2} \mathrm{SO}_{4}\right)$ through two phases of hydrolysis. The hydrolysis process using sulfuric acid will produce simple sugars [16]. The process was conducted for 30 minutes using an autoclave at a temperature of $121^{\circ} \mathrm{C}$, a pressure of $1 \mathrm{~atm}$. Reducing sugar was tested with the DNS method (3,5-dinitrosalicylic Acid) [17].

\subsection{Desalination}

The desalination process aims to eliminate the salt content in the hydrolysate which acts as an inhibitor in the fermentation process. The presence of salts can be an obstacle to obtain relevant performances [10]. Separation of undissolved salts was conducted by filtration or centrifugation and desalination to remove the dissolved salt by electrodialysis. Electrodialysis (ED) has the potential to cost-effectively separate ions from organics in bio-refinery effluents [18]. Cell consists of three chambers, namely the anode chamber, the feed chamber, and the cathode chamber, wherein each chamber lined with a filter 
to separate the salts deposits attached to the electrodes. The capacity of the feed chamber 150 ml. Hydrolysate incorporated in the feed chamber and the anode-cathode connected to a DC power supply. The process was performed at room temperature [19]. The electrodialysis process used an electrical voltage of 5, 9, and $12 \mathrm{~V}$ for 15, 30, and 45 minutes.

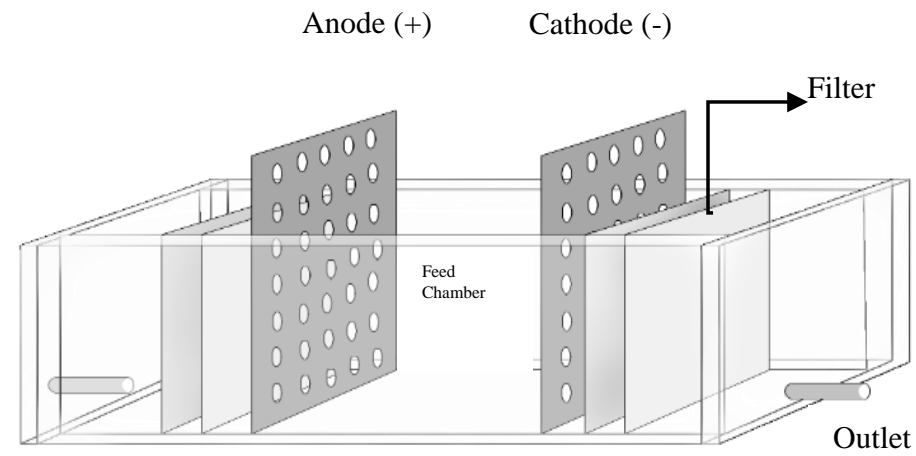

Fig 1. A three-chamber electrodialysis cell unit.

Electrodialysis cell unit used in this study as shown in Fig. 1. Tests were carried out after this process include total dissolved solids (TDS) with a TDS meter, salinity level with salinity refractometer, $\mathrm{SO}_{4}{ }^{2-}$ with turbidimetry method (ISO 06-6989.20-2004), and reducing sugars [17].

\subsection{Fermentation}

$\mathrm{pH}$, temperature, and time have a significant role in the fermentation process [20]. The fermentation process in this study was performed at room temperature for 6 days. Prior to fermented, $90 \mathrm{~mL}$ hydrolysate was pasteurized at a temperature of $70^{\circ} \mathrm{C}$ for 15 minutes to sterilize microbes that disrupt the process of fermentation. The fermentation microbe used was adapted Saccharomyces cerevisiae. Pure cultures of PDA media were taken by a sterile inoculating loop and rejuvenated at YMGP of $10 \mathrm{ml}$, then mixed with previously prepared hydrolysate, so the total volume was $100 \mathrm{ml}$. The fermentation process was conducted after the desalination process. The analysis performed was the measurement of reducing sugars [17], the number of cells with a hemocytometer, and ethanol content with Density Meter DMA 4500 M.

\section{Results and Discussion}

\subsection{Hydrolysate Volume}

Desalination was conducted by the electrodialysis method. The electrodialysis process is the development of an electrolysis process using electrodes connected to the electric current. Electrodes used were cathode and anode. The cathode acts as a negative pole so that positive ions (cations) will move towards the cathode, on the other hand, negative ions (anions) move toward the anode. Most of these ions will stick to the electrodes and will be filtered on an electrodialisator chamber equipped with a filter. Such a mechanism would lead to a decrease in the level of salinity and dissolved salts in the hydrolysate.

Hydrolysate used in electrodialysis was $100 \mathrm{ml}$. While the process was running, there was a decline in the volume of the hydrolysate. Analysis of variance showed that there was the influence of voltage, electrodialysis period, and its interaction to the volume of hydrolysate. Based on Fig. 2, at 5 and $9 \mathrm{~V}$, the decrease was relatively small. The highest decline occurred at $12 \mathrm{~V}$ for 45 minutes. Hydrolysate volume fell to $66.5 \mathrm{ml}$. The decrease occurred because the process using high voltage will cause the formation of foam or bubbles in the hydrolysate caused by water electrolysis.

Two water molecules responded to the cathode by capturing two electrons, which were reduced to $\mathrm{H}_{2}$ gas and hydroxide ions (OH-). While two water molecules break down into oxygen gas $\left(\mathrm{O}_{2}\right)$ at the anode, $4 \mathrm{H}+$ ions are released and electrons flow to the cathode.

Hydrogen and oxygen gas produced from this reaction formed bubbles on the electrode, thus partially retained on the filter causes the decline of hydrolysate volume. The reaction is as follows:

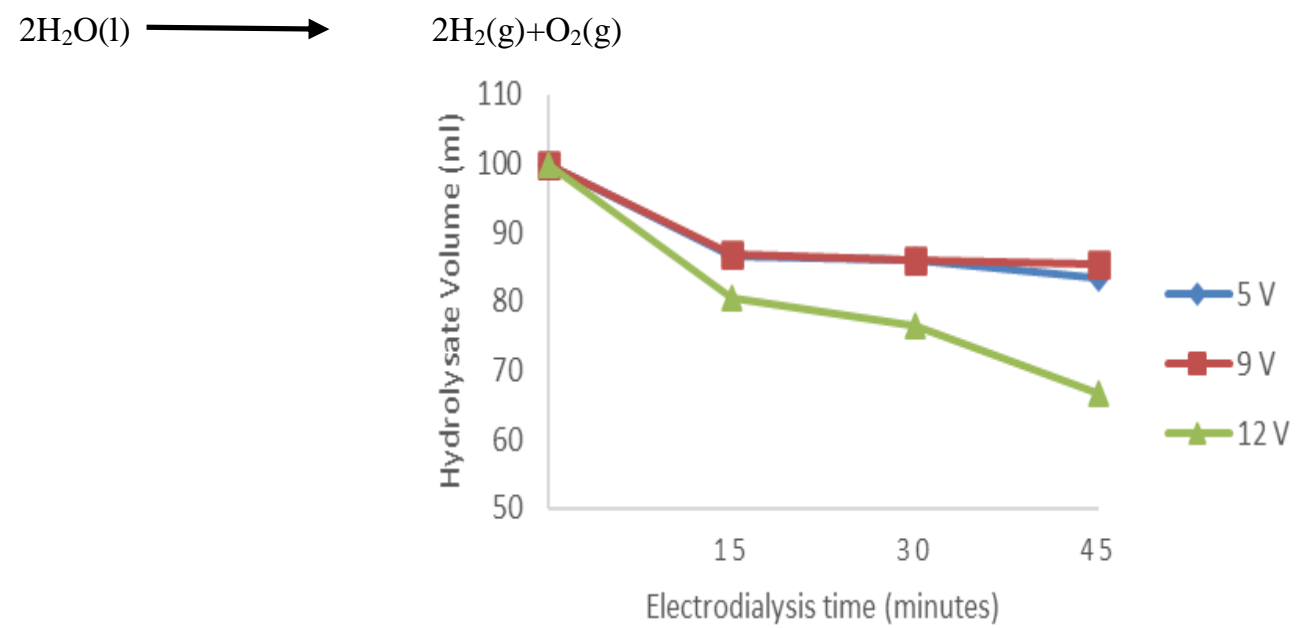

Fig 2. The effect of electrodialysis times and different electrical voltages to hydrolysate volume on desalination 


\subsection{Salinity and Salt Contents}

Based on Table 1, the lowest salinity level was $100 \%$ or salinity decrease of $20 \%$ at $5 \mathrm{~V}$ and treatment time of 30 minutes, $9 \mathrm{~V}$ and 15 minutes, $12 \mathrm{~V}$ and 30 minutes. In the minute of $45^{\text {th }}$, the salinity level increased. The increase in salinity occurred because of the reversible reaction. Analysis of variance showed that there was no influence for the treatment of voltage, while at electrodialysis times and their interaction showed that there was an influence on salinity level. In a further HSD test, contact time for 15 minutes and 30 minutes showed there was no significant difference to salinity level, but were significantly different at the $45^{\text {th }}$ minute. The combination of the electrical voltage of $5 \mathrm{~V}$ and 30 minutes contact time, $9 \mathrm{~V}$ and 15 minutes contact time, $12 \mathrm{~V}$ and 30 contact time were the best combinations that give the influence to decrease the high levels of salinity.

In the hydrolysate, dissolved salts could inhibit $S$. cerevisiae growth. These salts are derived from biomass and formed from the chemicals used for hydrolysis processes such as $\mathrm{H}_{2} \mathrm{SO}_{4}, \mathrm{CaOH}_{2}$, and $\mathrm{NH}_{4} \mathrm{OH}$. Ions and cations of the salts are potential as inhibitors such as $\mathrm{Na}^{+}, \mathrm{Cl}-, \mathrm{NH}_{4}^{+}, \mathrm{SO}_{4}{ }^{2-}$.

Table 1. The effect of electrodialysis time and different voltages to salinity level

\begin{tabular}{llrl}
\hline \multirow{2}{*}{ Voltages } & \multicolumn{3}{l}{ Salinity Level $(\% 0)$} \\
& $\begin{array}{c}15 \\
\text { Minutes }\end{array}$ & $\begin{array}{c}30 \\
\text { Minutes }\end{array}$ & 45 Minutes \\
\hline $5 \mathrm{~V}$ & $107.5 \mathrm{bc}$ & $100 \mathrm{c}$ & $117.5 \mathrm{ab}$ \\
$9 \mathrm{~V}$ & $100 \mathrm{c}$ & $115 \mathrm{~b}$ & $120 \mathrm{a}$ \\
$12 \mathrm{~V}$ & $107.5 \mathrm{bc}$ & $100 \mathrm{c}$ & $120 \mathrm{a}$ \\
\hline \multicolumn{4}{r}{} \\
\hline $5 \mathrm{~V}$ & \multicolumn{3}{l}{} \\
$9 \mathrm{~V}$ & 14 & 20 & 6 \\
$12 \mathrm{~V}$ & 20 & 8 & 4 \\
\hline
\end{tabular}

Initial salinity $=125 \%$

${ }^{a}$ The figures in the same column followed by the same letter are not significantly different at $5 \%$ level test.

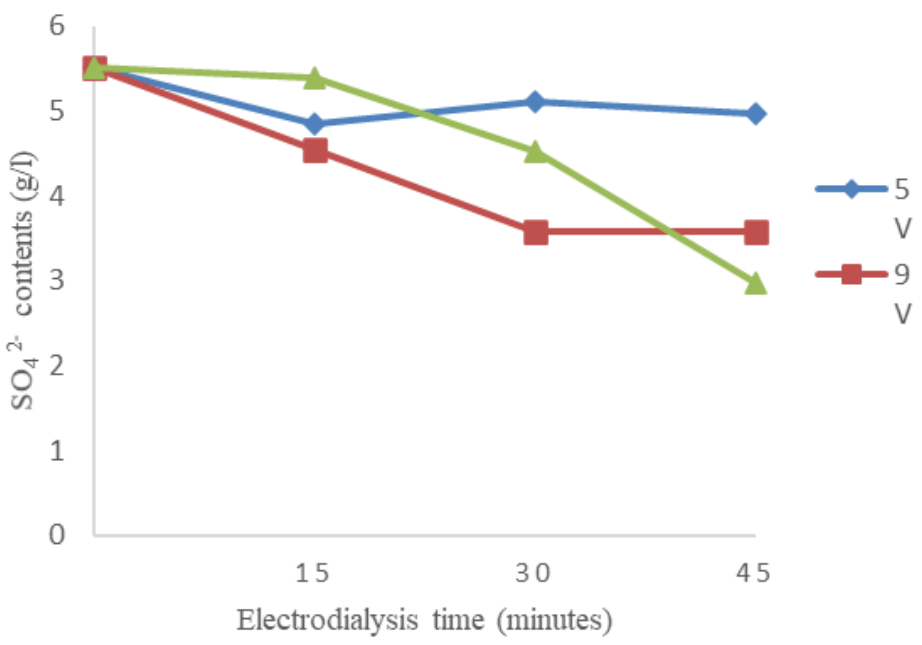

Fig 3. The influence of various voltages and electrodialysis time to $\mathrm{SO}_{4}{ }^{2-}$ content of the desalination process

In Fig. 3, the initial sulfate content of $5.52 \mathrm{~g} / \mathrm{l}$. all treatments showed a decrease compared to the initial sulfate content (control). The lowest sulfate decline occurred at a voltage of $12 \mathrm{~V}$ for 45 minutes. The content of sulfate in the treatment down to $2.97 \mathrm{~g} / \mathrm{l}$ or by $46.22 \%$. The higher reduction in sulfate through the electrodialysis process, the better the fermentation process is carried out. Analysis of variance showed that there was the influence of voltage, electrodialysis time, and its interaction to sulfate content.

The inhibition level of several types of cations on the growth of Zymomonas mobilis was as follows: $\mathrm{Ca}^{2+}>>\mathrm{Na}^{+}>\mathrm{NH}_{4}^{+}>\mathrm{K}^{+}[21]$. 0.5 $\mathrm{M} \mathrm{Na}^{+}$was able to inhibit the growth of $S$. Cerevisiae [22]. The study conducted by casey et al examined the inhibition influence of some type of salt on the growth of $S$. cerevisiae showed that only have the effect of $\mathrm{NaCl}$ salt resistance at low concentrations (below $0.2 \mathrm{M}$ ). While at higher concentrations $(1 \mathrm{M})$, the addition of $\mathrm{K}_{2} \mathrm{SO}_{4}$ and $\mathrm{Na}_{2} \mathrm{SO}_{4}$ caused a decrease in sugar consumption respectively by $12 \%$ and $33 \%$ compared with controls [23].

\subsection{Reducing Sugar and Total Dissolved Solids}

Galactan (8.2\%) and glucan (55.3\%) were the main polysaccharides in the extraction of carrageenan residues [24]. In Fig. 4, the results of the initial measurement of reducing sugar (control) amounted to $11.94 \%$ (w/v). There was a decrease in reducing sugar in all treatments except at a voltage of $9 \mathrm{~V}$ for 15 minutes. Reducing sugar in the treatment of $11.96 \%(\mathrm{w} / \mathrm{v})$. The highest decrease of reducing sugars was in treatment voltage of $12 \mathrm{~V}$ for 45 minutes, equal to $13.6 \%$. Reducing sugar in the treatment amounted to $10.32 \%$ (w/v). Analysis of variance showed that voltages and times did not give effect to a decrease of reducing sugar so that the process of desalination by electrodialysis was eligible to be applied. 


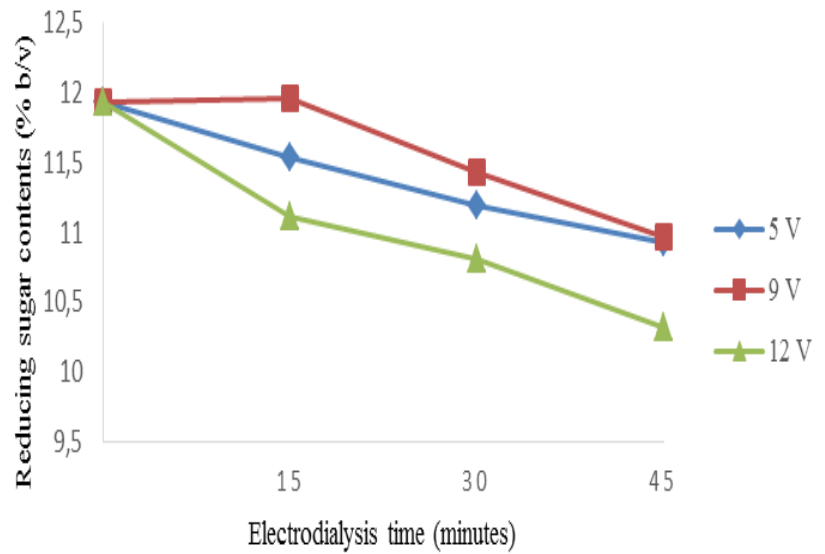

Fig 4. The influence of various voltages and electrodialysis time to reducing sugar content of the desalination process.

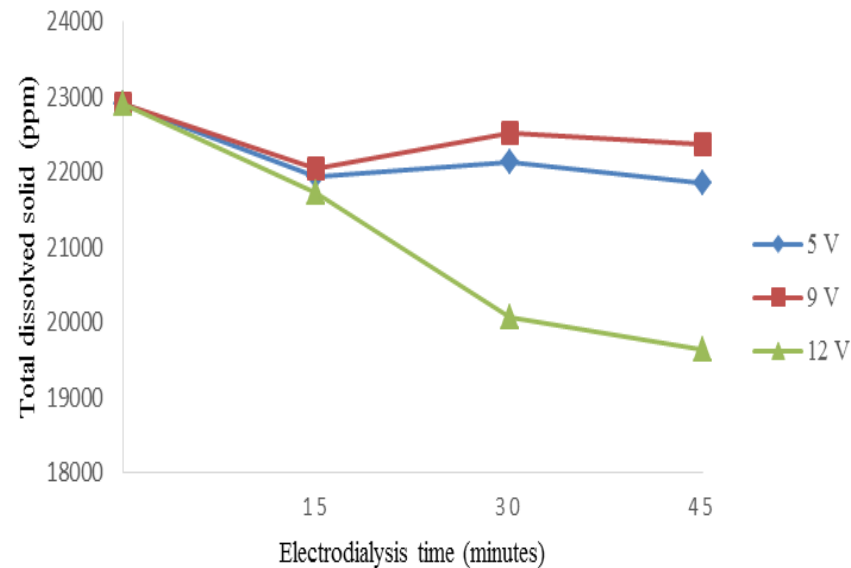

Fig 5. The influence of various voltages and electrodialysis time to total dissolved solid of the desalination process.

In Fig. 5, the initial TDS of 22,900 ppm. After the process of desalination by electrodialysis, TDS occurred a decline. TDS on treatment $5 \mathrm{~V}$ voltage, $9 \mathrm{~V}$, and $12 \mathrm{~V}$ for 15 minutes respectively 21,940 ppm, 22,040 ppm and 21,720 ppm. The largest decrease occurred on the 45th minute, which became $19,640 \mathrm{ppm}$.

Results of variance analysis showed that there was the influence of voltage treatment on total dissolved solids (TDS). In a further test $\mathrm{HSD}$, voltage $5 \mathrm{~V}$ and $9 \mathrm{~V}$ was not significantly different. Both the voltages $(5 \mathrm{~V}$ and $9 \mathrm{~V})$ were significantly different with voltage $12 \mathrm{~V}$.

\subsection{Fermentation}

Fermentation process at this stage using the hydrolysate neutralized with $\mathrm{Ca}(\mathrm{OH})_{2}$ and continued with the process of desalination by electrodialysis. Through this process, the level of salinity and sulfate content declined, so the fermentation process run well and produce an optimum yield of ethanol. The ethanol concentration increased as the use of substrates (glucose) by cells increased [25].

Table 2. The effect of desalination to fermentation process

\begin{tabular}{|c|c|c|c|c|c|c|}
\hline \multirow{2}{*}{ Treatments } & \multicolumn{2}{|c|}{ Reducing Sugar (\% b/v) } & \multirow{2}{*}{$\begin{array}{l}\text { Ethanol (\% v/v } \\
\text { Hydrolysate) }\end{array}$} & \multirow{2}{*}{$\begin{array}{l}\text { Ethanol } \\
\text { glucose) }\end{array}$} & \multirow{2}{*}{$\begin{array}{l}\text { Fermentation } \\
\text { Efficiency }(\%)\end{array}$} & \multirow{2}{*}{$\begin{array}{l}\text { Substrat } \\
\text { Efficiency }(\%)\end{array}$} \\
\hline & Before ferm. & After Ferm. & & & & \\
\hline Control & 11.17 & 8.03 & 0.77 & 0.18 & 40.16 & 28.07 \\
\hline $5 \mathrm{~V} \mathrm{15}$ & 11.97 & 5.82 & 1.90 & 0.23 & 50.58 & 51.41 \\
\hline 5 V 30' & 13.67 & 5.19 & 2.06 & 0.19 & 42.21 & 61.33 \\
\hline $5 \mathrm{~V} 45$ & 12.03 & 5.22 & 1.73 & 0.19 & 42.47 & 56.84 \\
\hline 9 V 15, & 11.74 & 6.49 & 1.69 & 0.24 & 52.52 & 45.03 \\
\hline 9 V 30' & 13.45 & 6.05 & 1.73 & 0.18 & 39.58 & 55.13 \\
\hline $9 \mathrm{~V} 45^{\prime}$ & 12.08 & 5.89 & 1.96 & 0.23 & 52.16 & 51.27 \\
\hline $12 \mathrm{~V} 15$ & 11.59 & 4.72 & 1.76 & 0.19 & 41.40 & 59.30 \\
\hline 12 V 30' & 12.14 & 5.75 & 2.00 & 0.24 & 52.91 & 52.49 \\
\hline $12 \mathrm{~V} 45^{\prime}$ & 10.70 & 5.57 & 1.51 & 0.22 & 48.79 & 47.92 \\
\hline
\end{tabular}


Based on Table 2, the treatment of desalination on the voltage of $5 \mathrm{~V}$ for 30 minutes was the best treatment for the highest ethanol yield, ie $2.06 \%$. Fermented microbes can still survive in such ethanol concentrations. At 7.5 percent ethanol levels, normal cell growth stopped, while the mutant strain tolerated up to 11 percent ethanol [26]. All voltages and longer treatment time in the electrodialysis process had a significant influence on the levels of ethanol. High levels of ethanol are produced allegedly due to a decrease of the salt levels in the hydrolysate after the electrodialysis process so that the fermentation process run better.

The presence of salt caused the increase of osmotic pressure and the ions gave inhibition influence on the high enough concentration [27]. The fermentation of algal sugars will be hampered by high salt content [28], [29]. Macroalgae hydrolysate salinity levels were high, reaching $125 \%$ [28]. The addition of $1 \mathrm{M}$ of $\mathrm{NaCl}$ to the medium would reduce the growth rate of S. cerevisiae by $70 \%$ [11]. In sugarbased media, S. cerevisiae may grow on $\mathrm{NaCl}$ of $1.5 \mathrm{M}$. Other compounds that acted as inhibitors were the phenolic compounds and other aromatic compounds, aliphatic acids, aldehydes, inorganic ions, and bio alcohol [30]. Also, furfural and HMF can influence the microorganisms metabolism hence diminishing yields and efficiency [31][32]. Methoxyacetophenone, apocynin, and syringaldehyde as inhibitors in fermentation are more than furfural in proportionate concentration [33].

\section{Conclusion}

The process of desalination by electrodialysis was able to reduce levels of dissolved salts and has a significant influence on the ethanol yield. Decreased levels of salinity and sulfate $\left(\mathrm{SO}_{4}{ }^{2-}\right)$ were $20 \%$ and $46.22 \%$ respectively. Desalination treatment at a voltage of $5 \mathrm{~V}$ for 30 minutes was the best treatment for the highest ethanol yield, ie $2.06 \%$. All voltages and longer treatment times in electrodialysis processes have a significant influence on the levels of ethanol yield.

\section{Acknowledgement}

This work was supported by Surfactant and Bioenergy Research Centre, IPB University, Indonesia.

\section{References}

[1] T. V. Ramachandra and D. Hebbale, "Bioethanol from macroalgae: Prospects and challenges," Renewable and Sustainable Energy Reviews. 2020, doi: 10.1016/j.rser.2019.109479.

[2] N. Dave, R. Selvaraj, T. Varadavenkatesan, and R. Vinayagam, "A critical review on production of bioethanol from macroalgal biomass," Algal Research. 2019, doi: 10.1016/j.algal.2019.101606.

[3] I. S. Tan, M. K. Lam, H. C. Y. Foo, S. Lim, and K. T. Lee, "Advances of macroalgae biomass for the third generation of bioethanol production," Chinese Journal of Chemical Engineering. 2020, doi: 10.1016/j.cjche.2019.05.012.

[4] L. P. Tuti Ariani, "The Effect Of Repetition Sprint Training Method Combined With The Level Of Physical Fitness Toward The Speed Of 100 Meter Run," Int. J. Eng. Sci. Inf. Technol., vol. 1, no. 3, 2021, doi: 10.52088/ijesty.v1i3.89.

[5] A. Ellis and J. C. Jacquier, "Manufacture of food grade א-carrageenan microspheres," J. Food Eng., 2009, doi: 10.1016/j.jfoodeng.2009.03.030.

[6] T. Imankulov, B. Daribayev, and S. Mukhambetzhanov, "Comparative analysis of parallel algorithms for solving oil recovery problem using cuda and opencl,” Int. J. Nonlinear Anal. Appl., vol. 12, no. 1, 2021, doi: 10.22075/IJNAA.2021.4809.

[7] I. S. Tan and K. T. Lee, "Comparison of different process strategies for bioethanol production from Eucheuma cottonii: An economic study," Bioresour. Technol., 2016, doi: 10.1016/j.biortech.2015.08.008.

[8] I. G. Dharma Utamayasa, "Efect Physical Activity and Nutrition During The Covid-19 Pandemic," Int. J. Eng. Sci. Inf. Technol., vol. 1, no. 1, 2021, doi: 10.52088/ijesty.v1i1.58.

[9] I. Y. Sunwoo et al., "Enhancement of Galactose Uptake from Kappaphycus alvarezii Hydrolysate Using Saccharomyces cerevisiae Through Overexpression of Leloir Pathway Genes," Appl. Biochem. Biotechnol., 2020, doi: 10.1007/s12010-020-03422-7.

[10] W. Sayed, A. Cabrol, R. Abdallah, S. Taha, A. Amrane, and H. Djelal, "Enhancement of ethanol production from synthetic medium model of hydrolysate of macroalgae," Renew. Energy, 2018, doi: 10.1016/j.renene.2017.10.094.

[11] M. J. García, G. Ríos, R. Ali, J. M. Bellés, and R. Serrano, "Comparative physiology of salt tolerance in Candida tropicalis and saccharomyces cerevisiae," Microbiology, 1997, doi: 10.1099/00221287-143-4-1125.

[12] Y. Khambhaty et al., "Kappaphycus alvarezii as a source of bioethanol," Bioresour. Technol., 2012, doi: 10.1016/j.biortech.2011.10.015.

[13] A. Salihin, A. H. Muhiddin, and I. Yasir, "EVALUATION STUDY OF EUCHEUMA COTTONII SPECIES OF SEAWEED CULTIVATION BASED ON OCEANOGRAPHIC PARAMETERS IN PASIEA, BONEGUNU SUBDISTRICT, NORTH BUTON DISTRICT," J. Ilmu Kelaut. SPERMONDE, 2020, doi: 10.20956/jiks.v5i2.8930.

[14] M. Jönsson, L. Allahgholi, R. R. R. Sardari, G. O. Hreggviosson, and E. N. Karlsson, "Extraction and modification of macroalgal polysaccharides for current and next-generation applications," Molecules. 2020, doi: 10.3390/molecules25040930.

[15] A. Susmozas et al., "Process strategies for the transition of $1 \mathrm{G}$ to advanced bioethanol production," Processes. 2020, doi: $10.3390 / \mathrm{pr} 8101310$.

[16] M. M. Ismail, G. A. Ismail, and M. M. El-Sheekh, "Potential assessment of some micro- and macroalgal species for bioethanol and biodiesel production," Energy Sources, Part A Recover. Util. Environ. Eff., 2020, doi: 10.1080/15567036.2020.1758853.

[17] G. L. Miller, "Use of Dinitrosalicylic Acid Reagent for Determination of Reducing Sugar," Anal. Chem., 1959, doi: $10.1021 / \mathrm{ac} 60147 \mathrm{a} 030$.

[18] A. Luiz, E. Spencer, D. D. McClure, H. G. L. Coster, G. W. Barton, and J. M. Kavanagh, "Membrane selection for the desalination of bio-refinery effluents using electrodialysis," Desalination, 2018, doi: 10.1016/j.desal.2017.11.006.

[19] L. J. Banasiak, T. W. Kruttschnitt, and A. I. Schäfer, "Desalination using electrodialysis as a function of voltage and salt concentration," Desalination, 2007, doi: 10.1016/j.desal.2006.04.038.

[20] S. A. Jambo, R. Abdulla, H. Marbawi, and J. A. Gansau, "Response surface optimization of bioethanol production from third generation feedstock - Eucheuma cottonii," Renew. Energy, 2019, doi: 10.1016/j.renene.2018.07.133.

[21] M. A. Franden, H. M. Pilath, A. Mohagheghi, P. T. Pienkos, and M. Zhang, "Inhibition of growth of Zymomonas mobilis by model compounds found in lignocellulosic hydrolysates," Biotechnol. Biofuels, 2013, doi: 10.1186/1754-6834-6-99.

[22] A. Almagro et al., "Effects of salts on Debaryomyces hansenii and Saccharomyces cerevisiae under stress conditions," Int. J. Food 
Microbiol., 2000, doi: 10.1016/S0168-1605(00)00220-8.

[23] E. Casey, N. S. Mosier, J. Adamec, Z. Stockdale, N. Ho, and M. Sedlak, "Effect of salts on the Co-fermentation of glucose and xylose by a genetically engineered strain of Saccharomyces cerevisiae," Biotechnol. Biofuels, 2013, doi: 10.1186/1754-6834-6-83.

[24] I. U. M. Roldán et al., "Chemical, structural, and ultrastructural analysis of waste from the carrageenan and sugar-bioethanol processes for future bioenergy generation,” Biomass and Bioenergy, 2017, doi: 10.1016/j.biombioe.2017.10.008.

[25] N. Lerkkasemsan and W. C. Lee, "Study of ethanol fermentation reaction using Saccharomyces diastaticus in a two-tank fermentation system with cell recycling," J. Taiwan Inst. Chem. Eng., 2018, doi: 10.1016/j.jtice.2018.06.001.

[26] S. Hossein Helalat, S. Bidaj, S. Samani, and M. Moradi, "Producing alcohol and salt stress tolerant strain of Saccharomyces cerevisiae by heterologous expression of pprI gene," Enzyme Microb. Technol., 2019, doi: 10.1016/j.enzmictec.2019.01.008.

[27] S. Helle, D. Cameron, J. Lam, B. White, and S. Duff, "Effect of inhibitory compounds found in biomass hydrolysates on growth and xylose fermentation by a genetically engineered strain of S. cerevisiae," Enzyme Microb. Technol., 2003, doi: 10.1016/S01410229(03)00214-X.

[28] J. Fakhrudin, D. Setyaningsih, and M. Rahayuningsih, "Bioethanol Production from Seaweed Eucheuma cottonii by Neutralization and Detoxification of Acidic Catalyzed Hydrolysate," Int. J. Environ. Sci. Dev., 2014, doi: 10.7763/ijesd.2014.v5.526.

[29] E. P. Knoshaug, T. Dong, R. Spiller, N. Nagle, and P. T. Pienkos, "Pretreatment and fermentation of salt-water grown algal biomass as a feedstock for biofuels and high-value biochemicals," Algal Res., 2018, doi: 10.1016/j.algal.2018.10.024.

[30] L. J. Jönsson, B. Alriksson, and N.-O. Nilvebrant, "Bioconversion of lignocellulose: inhibitors and detoxification.," Biotechnol. Biofuels, 2013, doi: 10.1186/1754-6834-6-16.

[31] L. R. Roque, G. P. Morgado, V. M. Nascimento, J. L. Ienczak, and S. C. Rabelo, "Liquid-liquid extraction: A promising alternative for inhibitors removing of pentoses fermentation," Fuel, 2019, doi: 10.1016/j.fuel.2018.12.130.

[32] B. Singh, P. Kumar, A. Yadav, and S. Datta, "Degradation of fermentation inhibitors from lignocellulosic hydrolysate liquor using immobilized bacterium, Bordetella sp. BTIITR,” Chem. Eng. J., 2019, doi: 10.1016/j.cej.2018.12.168.

[33] K. Watanabe, S. Tachibana, and M. Konishi, "Modeling growth and fermentation inhibition during bioethanol production using component profiles obtained by performing comprehensive targeted and non-targeted analyses," Bioresour. Technol., 2019, doi: 10.1016/j.biortech.2019.02.081. 